\title{
Choice and Evasion in Judicial Recognition of Governments: Lessons from Somalia
}

\author{
Mària Aristodemou *
}

\section{Introduction}

The role of judges in domestic legal systems and the question of how they decide or should decide cases have been the subject of extensive discussion, explanation, description and prescription for many years, with commentaries on the topic ranging from the normative, to the conceptual, to the empirical. The area has been the concern of, amongst others, legal philosophers, practising lawyers, sociologists of law and politicians for so long that one may venture to suggest, in the words of one wit, that even if we cannot pretend to be any wiser on this issue, we can at least claim to be better informed. Unfortunately, there is a dearth of similar writing on the role of judges and the nature of judicial decision-making in the intemational arena; by the latter I refer both to judges applying international law in international tribunals and judges called upon to examine elements of (or to deal with issues that have implications for) international law in domestic tribunals. This comment stems from the belief that although theories of adjudication addressing the domestic legal system may be concerned with similar issues and may illuminate our understanding with analogous insights, certain characteristics peculiar to international law and the international legal system make this area worthy of separate consideration.

The High Court's decision in Republic of Somalia v. Wodehouse Drake, ${ }^{1}$ demonstrates our courts' unwillingness to address issues relating to intemational law at the same time as exemplifying an area where the decisions of domestic courts can have important implications beyond the domestic arena. The question before the court was who, if anyone, was entitled to the proceeds from the sale of a cargo of rice which, as a result of the civil war in Somalia, had not been delivered. The deposed Government of Somalia had bought and paid for the rice in December 1991 but a new interim government set up at an international peace conference in July

$$
\text { Briscol University. }
$$

[1993] 1 All ER 1.

5 EJIL (1994) 532-555 
1992 was claiming the proceeds. Hobhouse $\mathrm{J}$ decided that neither the interim government nor any of the other warring factions in Somalia could be regarded as the Government of Somalia and therefore the money would be kept in court until and unless a group could prove to the court's satisfaction that it was the Government of Somalia.

At first glance the case can inform us about how our courts deal with unrecognized entities, what standards they require before taking cognisance of the latter and whether any change has become apparent as a result of the UK Government's decision in 1980 not to accord recognition to governments. However, given the real human tragedy behind the facts of this case, and the possibility that our judges may today exercise more discretion on this issue than they did in the past, it seems appropriate to raise questions beyond that of whether the decision is in accordance with precedent. In particular, one may enquire into what choices and standards are available to our judges in such instances, what the ideological assumptions behind such choices are, how judges perceive their role in this area and towards international law in general and how such issues relate to their position in the two legal systems in which they are required to operate.

Taking Somalia as a springboard from which to examine these issues, this article argues that although international law differs in nature and sources from domestic law, when dealing with an international law issue our judges follow the same, broadly positivistic, approach in their decision-making familiar from the domestic system: they claim, that is, to base their decisions on 'facts' which can be proved or disproved and refrain from explaining the value judgments inherent in their choices. In the particular task of choosing between competing regimes, the effect of this approach is to avoid, not making, but expressing the value judgments intrinsic to their work, to accord priority to some values over others and to reinforce the status quo. By unravelling the value judgments hidden in such decisions, and specifically in the test of effectiveness, one may discern our courts' reliance on an assumed but ' unacknowledged understanding of the purposes of the law, uncover the underlying conflicts between such purposes and reveal the indeterminacy and relativity of the standards our courts purport to apply. At the same time, the comment affirms the inevitability, and urges the acknowledgment, of the exercise of choice in judicial decision-making. By situating the Somalia case within the positivist and, more generally, the modemist project of separating fact from value, it argues that although both this choice and this indeterminacy are endemic to judicial decision-making, domestic or international, the clearer we are about the choices open to our judges the better. On the domestic level, if this judgment signals our judges' willingness to go beyond and behind pronouncements by the Foreign Office to reach their own decisions on the issue, the desirability of developing and revealing the principles on which those decisions are reached, and the need for our judges to explain how they view their role in the international sphere, is essential. On the international plane, claims concerning the arrival of a New World Order and a new era for international law, accompanied by attempts to enforce this order by military means, make this 
Mària Aristodemou

inquiry more urgent than ever. For it is the assumption behind this inquiry that judicial decisions in this, as in other areas, are never self-determining and, even less, self-justifying.

\section{International Law and the Recognition of Governments}

One of the prerogatives of any legal system is to determine who or what are the entities entitled to derive benefits or to be subjected to duties under its jurisdiction. In this, as in other areas, international law has sought to imitate domestic law, but, as in other areas, the imitation is at best hesitant and incomplete, at worst unsuccessful and futile. This state of affairs is not unusual for international law, perpetually torn, as it is, between trying to regulate the relations between States on the one hand and relying on States to regulate themselves for its own definition and existence on the other. In these circumstances, the minimum requirement for the emergence of an international norm from the vagaries of the state of nature is an understanding between States that regulation, albeit an infringement on their freedom is, at least in the long term, in their own best interests.

It is the fact that this prerequisite has not been universally accepted in the field of recognition of governments that has made international law's attempts to regulate the entry of new entities into its system so problematic. Progress in this area has been hampered by States' unwillingness to be deprived of a valuable political instrument in their dealings with other States: extending or refusing recognition to an entity can, and is, of course used to obtain for oneself or to deny to another a political advantage. In addition, even if States acknowledge, albeit reluctantly, that international law may have an interest in regulating the entry of international persons (such as States) into its system, the case that governments, the all-too temporary agents of States, also merit or require such regulation has not been made to their satisfaction. Moreover, if the criteria intemational law has advanced over the years for the recognition of new States have been less than rigid, the criteria for recognizing new governments have, if anything, been even more fluid. Requirements such as constitutionality, respect for the wishes of the people, necessity, willingness to fulfil one's international obligations have all been put forward by different governments and at different times. Successive United Kingdom Governments relied on yet another criterion, that of effectiveness: an entity able to exercise effective control over a particular territory would be recognized as that territory's government, irrespective of whether the international community or Her Majesty's Government approved of that entity. ${ }^{2}$

None of these criteria, however, could claim to have attained the status of customary international law, especially as they were not being applied consistently 
even by the States purporting to enunciate them. Added to this is the argument that as international law regulates the affairs between but not within States, it would be insulting to, if not an unjustified interference in, another State's affairs to issue judgments as to the desirability, legitimacy or viability of its new government. It is such considerations that led an increasing number of countries to follow the lead of the Mexican statesman Estrada in ceasing to extend recognition to governments. This policy was adopted by the British Government in $1980 .{ }^{3}$ According to Lord Carrington, Her Majesty's Government would no longer accord recognition to governments: instead, the question whether it qualifies to be treated as a government would be left to be inferred from the nature of the dealings, if any, which Her Majesty's Government has with them. The decision of what dealings the British Government would have with regimes that came into power unconstitutionally would itself be taken on the basis of whether they are able of themselves to exercise effective control over the territory in question. ${ }^{4}$ The criterion of effectiveness, therefore, remained paramount.

The popularity of the Estrada doctrine stems from the fact that it relieves governments from having to make difficult, sensitive and often embarrassing choices between competing regimes. It enables them, if they so choose, to have dealings with more than one regime in the same State without having to express approbation or disapprobation of any of them. Such flexibility is not of course available to domestic courts that may be called, from time to time, to adjudicate on the validity of acts taken by entities whose authority to take such acts is unclear. When such a case arises the courts have no choice but to reach a decision which will involve making a judgment on the status of the new regime. The source and content of the criteria they use to make this judgment are not of course self-determining but a matter of choice: whether they seek guidance from intemational law, domestic law, Her Majesty's Government, or elsewhere, the selection, interpretation and application of that guidance remain theirs. The following section will look at how English courts have exercised this choice in the past and to assess whether any changes are likely to follow in the future.

\section{The Approach of English Courts}

Despite Hans Kelsen's aspirations that domestic law would regard international law as the highest echelon in every rational reconstruction of a legal system, ${ }^{5}$ our courts' attitude to international law has remained firmly dualist: international treaties have

3 The United States have always claimed that recognition is a discretionary tool: see 1977 US Department of State Statement [1977] U.S.D.L.L. 19 and L.T. Galoway, Recognizing Foreign Governments: The Practice of the United States (1978). See also Peterson, 'Recognition of Governments Should Not Be Abolished', 77 AJIL (1983) 31.

4 H.C. Deb. Vol. 983, Cols. 278-279, H.C. Deb. Vol. 985, Cot. 385.

5 H. Kelsen, Principles of Intemational Law (2nd ed., 1967) at 553. 
to be specifically transformed into UK law before English courts will give effect to their provisions. ${ }^{6}$ And although customary international law is alleged to form automatically a part of our law, this rarely happens in practice: international law, unlike domestic law, is not assumed to exist in and by itself but its existence must be proved to the courts' satisfaction 'as a matter of fact'. ${ }^{7}$ In general, our courts' unfamiliarity with international law and the difficulty of proving the existence of a principle of customary law, has in the past led our judges to resort to the safety of domestic law or to directions from Her Majesty's Government.

In the area of recognition of governments, where international law is thought to be undecided about its own criteria, it was even more likely that our judges would throw themselves wholeheartedly into the arms of the Foreign Office. Some judges may therefore regret the passing of the days when the Foreign Office certificate would determine for them conclusively how to treat new entities: if the latter had been recognized, all the rights and duties conferred by international and domestic law on such entities were automatically and unconditionally accorded to it. If it had not, as far as English law was concerned it was non-existent and its standing was no different from that of an animal in the domestic legal system. ${ }^{8}$ In the words of Donaldson MR when dealing with the analogous position of an international organization, 'once it is touched by the magic wand of an order in Council it becomes a person. Until then it is not a native, nor is it a visitor from abroad. It comes from the invisible depths of outer space'. 9

The practice of following Foreign Office certificates concerning new regimes was meant to ensure that the executive and the judiciary spoke with the same voice; however, this did not prevent judges from occasionally looking behind the Foreign Office certificate if they were not satisfied with the outcome such an approach would dictate. ${ }^{10}$ The fact that Her Majesty's Government did not consistently observe its own criteria and often, for political reasons, failed to recognize governments that were in effective control, made this divergence even more likely,

6 For a recent example see Maclaine Watsan $v$. Dept of Trade [1989] 3 All ER 523, 544-545.

7 See for example West Rand Central Gold Mining Co. v. R. [1905] 2 K.B. 391 per Lord Alverstone CJ.: 'it is quite true that whatever has received the common consent of civilized nations must have received the assent of our country... But any doctrine so invoked must be one really accepted as binding between nations, and the international law sought to be applied, mush, like anything else. be proved by satisfactory evidence' (at 406-7).

8 Ciry of Beme v. The Bank of England [1804] 38 Ch. D. 357.

9 Arab Monetary Fund v. Hashim [1990] 2 All ER 769 at 775 f.

10 See for instance obiter by Lord Wilberforce in Carl Zeiss Stiftung v. Rayner \& Keeler Led (No. 2) [1966] 2 All ER 536 to the effect that courts may enforce the acts of an unrecognized entity where private rights, or acts of everyday occurrence or perfunctory acts of administration are concerned' (at 577). See also Lord Denning in Hesperides Hotels v. Turtish Aegean Holidays [1978] I All ER 277: 'the courts of this country can recognize the laws or acts of a body which is in effective control of a territory even though it has not been recognized by Her Majesty's Government de jure or de facto, at any rate in regard to the laws which regulare the day to day affairs of the people, such as their marriages, their divorces, their leases, their occupations and so forth; and furthermore that the cours can receive evidence of the state of affairs so as to see whether the boty is in effective control or nox' (at 283). 
with the courts rescuing the acts of unrecognized governments from invalidity by treating them as the acts of another, recognized government. 11 Whether the decision to stop recognizing governments would encourage our courts to form their own judgments more often in the future, in the way their American counterparts do, has already been the subject of much comment. Many pointed out that although there would no longer be any formal acts of recognition, the substantive criteria for entering into relations with new regimes (i.e. effectiveness) remained the same and thus no great changes in the attitude of our courts need be anticipated. ${ }^{12}$

In Republic of Somalia $v$. Wodehouse Drake, ${ }^{13}$ Hobhouse J confirmed that in the absence of recognition by Her Majesty's Government the main criterion for the courts to apply was whether the regime is able of itself to exercise effective control of the territory of the State concerned and is likely to continue to do so. Another criterion is the attitude of Her Majesty's Government which can be inferred from the nature of the dealings, if any, that it has with the new regime and whether they are on a normal government to government basis. He made it clear, however, that Her Majesty's Government's actions were only part of the evidence to be considered and were not conclusive of the issue whether an entity was a government or not:

the conduct of governments in their relations with each other may be affected by considerations of policy as well as by considerations of legal characterization. The courts of this country are now only concerned with the latter consideration. 14

This point was emphasized further.

Once the question for the court becomes one of making its own assessment of the evidence, making findings of fact on all the relevant evidence placed before it and drawing the appropriate legal conclusion, and is no longer a question of simply reflecting government policy, letters from the Foreign and Commonwealth Office become merely part of the evidence in the case.

And,

now that the question has ceased to be one of recognition, the theoretical possibility of rebuttal must exist. 15

Applying these principles to the facts of the case, Hobhouse $\mathrm{J}$ began by taking into account the fact that Her Majesty's Government maintained informal contact with all the factions in the Somalia conflict but had no dealings on a government to

11 See Carl Zeiss Stiftung v. Rayner \& Keeler supra note 10, and Gur v. Trust Bank of Africa [1986] 3 All ER 449.

12 See, e.g. Symmons, 'UK Abolition of Recognition of Governments: A Rose by Another Name?', [1981] Public Low 249; Warbrick, 'The New British Policy on Recognition of Governments', 30 ICLQ 568 (1981).

13 Supra note 1.

14 Ibid, at 380e.

15 Ibid, at $381 \mathrm{j}-382 \mathrm{~b}$. 
government basis with any of them. He looked, and found support, for the British Government's view that there was no effective government in Somalia from other evidence such as reports by the Agency for International Development. The fact that the interim government was set up at an international conference, he said, did not affect this, nor did the fact that it was given a degree of recognition by some States and at the United Nations. There was a difference, he thought, between a constitutional government and an insurgent regime: although a loss of control by the constitutional government would not deprive it of its status, an insurgent regime must establish effective control before it can exist as a government. ${ }^{16}$ Furthermore, although recognition is a relevant factor, it cannot rebut the overwhelming evidence that the regime exercised no administrative control over the territory. ${ }^{17}$ This is, again, because States often, for policy rather than legal reasons, have relations with bodies that are not governments or States.

Accordingly, the factors to be taken into account in deciding whether a government exists as the government of a state are:

(a) whether it is the constitutional government of the state;

(b) the degree, nature and stability of administrative control, if any, that it of itself exercises over the territory of the state;

(c) whether Her Majesty's government has any dealings with it and if so what is the nature of those dealings; and

(d) in marginal cases, the extent of international recognition that it has as the government of the state. 18

As the interim government of Somalia did not satisfy these criteria the disputed money would remain in court until an entity could prove that it was the Government of Somalia.

According to one commentator

the advance this judgment makes is to prise away the question of who is the government for international, political purposes from the question of who it is for domestic legal purposes. 19

The case has also been welcomed as a robust new approach by our courts which finally obliterates the unsatisfactory distinction between de facto and de jure governments and which makes it clear that 'for judicial purposes at least, the only government is a securely established government'. ${ }^{20}$ This writer is less sure whether any great advance can be discerned from this judgment: as will be argued in the next section, not only does the test of effectiveness remain paramount but the underlying basis of the decision is what it has always been: a broadly positivistic approach

Ibid, at $383 c$.

Ibid, at $383 \mathrm{~h}$ and $384 \mathrm{~d}$

Ibid, at 384e.

Warbrick. 'Recognition of Governments', 56 MLR 92 (1993) at 96.

Crawford, 'Who is a Government? The Execurive and the Cours', Combridge Low Joumal (1993) 4 , at 6. 
which, by pretending to be able to divorce fact from value, accords significance to some values over others and has the effect of maintaining the status quo.

\section{Positivism and the Test of Effectiveness: Law, Fact and Value}

The first and fundamental assumption made by the judgment is that one can distinguish between 'legal' and 'political' criteria in this, and in all, contexts. In particular, Hobhouse $\mathbf{J}$ implies that effectiveness is a legal rather than a political criterion. The issue therefore becomes one of finding the test whereby what is legal may be distinguished from what is political and what makes the criteria chosen here distinctly legal rather than political. This question is at the root of theories concerned with the nature of judicial decision-making, whether their object is to describe, explain, justify or criticize the power vested in the hands of the judiciary in our society.

The desire to separate legal from other criteria (whether political, religious, moral, or other) was at the root of legal positivist thinking with its reliance on observed, identifiable facts as distinct from questions of value or purpose. Positivists aimed to portray the existence of a legal system, and the rules contained therein, as a matter of 'fact' which can be proved or disproved: the populace's habitual obedience, the effectiveness of a legal system, the acceptance by officials are all assumed to be capable of factual verification. The separation of law from other standards, however, is not easy to achieve, even in theory: Austin's view that law can be identified and divorced from other standards of behaviour by reference to the 'fact' of habitual obedience was rejected by Hart who saw normativity as the distinguishing characteristic of a legal system. But the leading role played by the 'officials' in Hart's own system, and the fact that it is the judges who identify and apply the Grundnorm in Kelsen's system show that even in a so-called 'developed' system, the distinction between legal and political criteria will not be dictated by the system itself, however perfect its rational reconstruction, but by the human agents operating that system. None of the leading positivists succeeded, therefore, in banishing all forms of societal value from their definitions of the legal system.

One may protest, of course, that these theorists never purported to offer advice in such cases: concerned with finding out what the law is, rather than what it ought to be, and with providing advice to practitioners, rather than judges, they offered no criteria for choosing between competing regimes in a scenario such as Somalia. As Finnis complained, positivist theories have no temporal dimension: rules exist here and now and its followers are both unwilling and unable to give an account of law in the long term. ${ }^{21}$ However, positivists can be criticized for ignoring, and often

21 For Finnis, what is important is to explain why legal systerns 'continue' - something that cannot be explained by referring to the basic norm since 'legal systems can no more be explained by reference to sequences of events than can motion be explained by reference to sequences of 
suppressing, legitimate questions such as the nature and basis of law-making authority and the fact that decisions concerning the latter need to be made and the premises on which they are reached should be made clear. More importantly, all theories contain ideological assumptions which will affect the judges' perception of their role: Austin's reliance on habitual obedience as the linchpin of the whole system, for example, and his insistence on sanctions, suggested that crude physical power is the determining feature of a legal system. Kelsen's precondition of effectiveness and emphasis on sanctions further confirmed the correlation between law and power and led to the criticism that he espoused the doctrine that might is right. ${ }^{22}$ In the same way, the judgment for the choice and content of law in Hart's configuration of the legal system is for the officials and will be assumed when the majority of the population already follow the system's primary rules whilst the officials have a critical reflective attitude towards the system's secondary rules. This again, albeit surreptitiously, elevates the position of the officials at the expense of the people.

The view that the separation of law from policy, morality and purpose is artificial at best is, of course, not new: Fuller, for one, insisted that what the law is on any particular issue cannot be adequately answered or described without taking into account law's purpose. ${ }^{23}$ Although Fuller had no doubts as to what law's purposes were, it cannot be denied that different people and, of course, different judges will entertain different views on this issue. A judge's interpretation of the law will therefore be coloured by his or her subjective understanding of the aims of the law. Similarly, as we learned from the realists, law does not come to us neatly demarcated from its wider social context, and the rules it purports to enunciate are capable of a variety of interpretations. ${ }^{24}$ Dworkin has further shown that it is impossible to divorce legal from moral criteria by reminding us that positivist sources do not exhaust the material our judges refer to when making their decisions. ${ }^{25}$ Recent inquiries into the nature of interpretation, the emphasis on the malleability of language, and the despair at one's ability to control the meaning of words only reinforce this understanding: we are being constantly reminded of our inability to work outside language, that language cannot, as was once assumed, express an objective reality, and that language interprets and constructs, rather than

points': E Vogelin, The Nanure of Low unpublisbed paper quoted in Finnis, 'Revolutions and Continuity of Law', in A.W. Simpson (ed), Oxford Essays in Jurisprudence (1973) at 69.

22 Kelsen himself would bave denied this inference arguing that what he was doing was reporting. but noo approving the fact that for a legal system to exist it had to be by and large effective; but even those willing to accept this point worry that Kelsen's position invests effective coercion with disproportionate value: see. e.g., Hughes, 'Validity and the Basic Norm', 59 Califomia Law Review (1971) 695.

23 L.L. Fuller, The Morality of Law (1964); see also D. Beyleveld and R. Brownsword, Law as a Moral Judgment (1986).

24 See, e.g., Singer, 'Legal Realism Now', 76 Califomia Low Review (1988) 465.

25 Dworkin, 'The Model of Rules', 35 University of Chicago Low Review (1967) 314 and 'Hard Cases', 88 Harv. L Rev. (1975) 1057. This thesis is elaborated and refined in his Taking Rights Seriously (1978); A Matter of Principle (1985); and Law's Empire (1986). 
Choice and Evasion in Judicial Recognition of Governments: Lessons from Somalia

simply represents, reality. It is therefore not only arrogant, but wrong, to assume that we have complete control over the meaning and effect of our words: our attempt to make sense of the world will be frustrated and deflected by the words we choose as well as the interpretation put on them by our audience and readers. ${ }^{26}$ Even our ability to describe physical events loses its purported innocence in the hands of writers such as Baudrillard who questions our ability to differentiate between true and false, between real and imaginary. ${ }^{27}$

In the final analysis, one cannot give an objective account of what something is without making value judgments as to what that something should be; even the order in which one chooses to describe their object involves making (inevitably subjective) assumptions about what is important and worthy of utterance about that object. As Wittgenstein taught, our attempts to define an object or an activity will be guided by the purpose for which we are seeking the definition and the latter will be 'created', rather than 'found', by the conceptual categories we bring into the exercise. ${ }^{28}$ In that sense, language can constitute rather than reflect reality and the terms we use will affect, and not just reflect, our meaning. Although positivists assumed they could describe what the law is without making any value judgments as to what it should be, their definitions are based, just like everybody else's, on an (unexpressed) understanding of the purpose of law. Both the definitions and the conceptual categories used to create them are therefore just one, but not the only, way of categorizing the world. At the same time, the positivists' optimism in expressing a pure, self-authenticating reality and truth and, with that, our judges' hope to solve disputes without reference to extra-legal criteria, remain as remote as ever.

\section{Law, Fact and Value in International Law Theory}

If judges cannot base their decisions on facts because the distinction between fact and value is untenable and the facts themselves hide value judgments, on what basis, if any, do they choose between competing regimes? If the judges' interpretation of what the law is cannot but be coloured by their understanding of the law's purpose, what is that understanding and that purpose? In particular, are judges looking for the purpose of international law or of municipal law? Is the purpose of international law the same as that of domestic law and how should an issue that straddles both systems be adjudged? When in a case such as Somalia the

26 At the forefront of these investigations is of course the work of Jacques Derrida on how the philosopher's project is constantly deflected by lenguage; since philosophy cannot escape the constraints of language (any more than poetry), attempts to differentiate between different types of language are doomed to fuil; all language is metaphorical rather than literal: Margins of Philosophy (1972).

27 See for example his argument that the Gulf War never happened: The Guardian. 11 January 1991 and 29 March 1991; and generally M. Poster (ed), Jean Baudrillard: Selected Writings (1989).

28 L. Wittgenstein, Philasophical Investigations (G. Anscombe trans. 1958) at 30. 
implications of their decisions go beyond the domestic arena, these questions cannot be answered without enquiring into the purpose of international law and whether there are any guiding international law criteria for the recognition of new governments. It is at this point that a judge's fidelity to the two systems in which (s)he is called upon to operate is put to the test: on the one hand his or her decisions can affect areas and peoples outside the court's jurisdiction. On the other, (s)he can justifiably protest that (s)he cannot be expected to take cognisance of international law principles without enquiring into that system's own claim to legitimacy and binding force.

Like legal theorists in general, international law scholars have been absorbed with the idea of developing some conceptual way of differentiating between law and politics; such a formula, it is hoped, would help explain the binding authority and legitimacy of the system. Whilst at first the explanation for this binding authority might have been provided by divine revelation or a belief in a natural law of nations, with the Enlightenment international lawyers became as keen to restrict themselves to factual accounts and explanations as their colleagues on the domestic plane. Grotius' views about the nature and purpose of international law were thus replaced in the eighteenth century with Vattel's explanation of international law on the basis of historical and social phenomena, in other words 'facts' which could be observed; the aim, in short, was to render intemational law as scientific as domestic systems. ${ }^{29}$ Kelsen's view that international law is about the rights and duties of individuals rather than States and his espousal of monism over dualism was similarly the idealism of a scientist aspiring to construct a pure, consistent and selfsufficient theory of law. ${ }^{30}$ In his reconstruction of the international system, the standards international law is invoked to apply are not ideological but pure:

coercion of state against state ought to be exercised under the conditions and in the manner that conforms with the custom constiurted by the actual behaviour of states. 31

The positivist thread thus enabled the system to be seen as universal, formal, rational and value-free and post-Enlightenment international law could, like domestic law, pride itself on being based not on faith but on reason and facts.

Faced further with the challenge from legal and political realists that law is indistinguishable from politics, ${ }^{32}$ international lawyers turned their attention to devising procedures for the settlement of disputes rather than proposing substantive

Vatuel's Droir des Gens ou Principles de la Loi naturelle appliqués aux affaires des Narions et des Souverains (1758) is thus considered to mark the revolution from a theological or passionate conception of international law into a secular or rational conception: see M. Koskenniemi (ed.), Insemational Law (1992) at xiii.

30 He is thus able to contrast his 'scientific theory of international law' with the 'political ideologies' of other theorists: supre note 5 , at viii.

31 lbid

32 See, e.g., H.J. Morgenthau, Politics Among Nations: The Struggle for Power and Peace (4th ed. 1967); and G. Kennan, American Diplomacy 1900-1950 (1951). 
goals which were likely to differ from State to State. ${ }^{33}$ Even those dissatisfied with the realist retreat from substantive rules and goals often conceded that law can never determine an outcome and restricted themselves to demonstrating the relevance of law to State action, arguing that international law forms part of the context in which States reach their decisions, albeit not the whole of that context. ${ }^{34}$ Under this conception of international law, the task of the international law theorist and the practising lawyer was not to derive normative propositions from a divine authority or a timeless conception of justice and right but instead to determine how sovereigns should behave from the way States already behaved. This role called for no value judgments, for critiques, or for choices between different forms of State action.

The explanation for the binding force of international law accompanying these accounts was found in broad liberal principles similar to those reigning on the national level: States are bound by rules determined by the States themselves in the ritual of State practice in which they all take part. In the same way that men submit their unlimited freedom in the state of nature to Hobbes' Leviathan, States submit their power to do as they will out of enlightened self-interest, based on the assumption that their long-term interests coincide with those of the international community. Indeed, according to one theorist, "the language of international law has to be understood historically as no more than a subsystem of the discourse of liberal political theory'. 35

However, given international law's attempt to base its legitimacy on the same broad principles as domestic law, it is not surprising that when the liberal conception of the State and the purposes and underlying principles of the domestic system come under attack, the legitimacy of the international system should come under similar scrutiny. The liberal conception of international law as a system of rules divorced from State practice and political opinion is faced with the problem that different jurists often derive different rules from their observations of what should be the same set of facts. Furthermore, even if there is agreement on the rules, the application and interpretation of those rules is often a matter of dispute. As shown above, the hope that politics can be constrained by rules is based on the assumption that neutral interpretation is possible and ignores the fact that the language used to express those rules is often contingent, political and indeterminate. This means that if accusations of indeterminacy and contradiction have made it difficult for law and judicial decision-making to maintain the appearance of neutrality in the domestic legal system, the likelihood that the international system would escape such accusations is remote. ${ }^{36}$ The grand old dilemma of liberal

33 For a description of this process see Kennedy, 'A New Stream of International Legal Scholarship'. 7 Wisconsin Joumal of Intermational Low (1988) 1.

34 'In none of the problems presented in this book is law determinative of every issue. But in all of them law is relevant and the role of lawyers is important': A. Chayes, T. Ehrlich, A.F. Lowenfeld, International Legal Process: Materials for an Introductory Course (1968) at xii.

35 Carty, 'Critical International Law: Recent Trends in the Theory of International Law', 2 EIL (1991) at 66.

36 See D. Kennedy, Intemational Legal Structures (1987). 
political theory between law and order, compulsion and consent becomes all the more blatant in the international system where both the creation of the norms as well as their enforcement depend on the subjects' consent. Accusations of inherent contradictions seem all the more justified in a system that on the one hand purports to constrain, whilst on the other invites, and relies on, its subjects to participate in and create their own constraints. ${ }^{37}$ As another commentator puts it, liberal theory cannot exalt State sovereignty and independence at the same time as requesting States to behave in accordance with a social custom. ${ }^{38}$

When one looks at specific international law rules these accusations seem even more well founded; fertile ground for unravelling the indeterminacy and contradictions of the latter have of course been provided by the principle of selfdetermination (which seems to admit of as many interpretations as there are discussions of the concept) and the difficulty of reconciling it with the principle of territorial integrity. ${ }^{39}$ Conflicts also arise in the United Nations' own purposes and principles which seek to affirm the importance of a State's sovereignty and political independence at the same time as aiming to protect individual human rights. Problems of indeterminacy in the rules to be applied and contradictions between the rules and underlying principles are compounded in cases such as Somalia where a court is asked to operate in two systems at the same time. At least one such contradiction lies in the purported purpose of these two systems: international law has traditionally focused on the rights and duties of collectivities, predominantly States, only recently turning its attention to individuals as possible subjects of its jurisdiction. The whole basis of English domestic law, on the other hand, is the rights and duties of individuals, only recently turning its attention to collectivities such as group rights. This contradiction, however, goes unacknowledged in cases such as Somalia which straddle the two legal regimes; instead, our judges look at what they are used to looking at, that is the contest between the rights and duties of individuals, in this case the buyer and seller of rice, rather than the interests of (to them) unfamiliar entities such as governments, States or the international community. ${ }^{40}$ In this equation, the rights appealed to and enforced are firmly rooted in a Hohfeldian understanding of rights as correlative to duties and Hart's concept of the nature of rights as affirming an individual's freedom of choice. That the rights

37 For a similar argument see $\mathbf{M}$. Koskenniemi: 'The very assumptions behind customary international law provide the mectanism for its self-destruction' in 'The Politics of Intermational Law', I EJIL (1990) 4, at 26.

38 Carty describes the dilemma of liberalism as one between a project that purports to be rational bur at the same time having to present itself as based on tradition or social practice; the two, he argues, are incompatible: see A. Carty, The Decay of Intemational Law: A Reappraisal of the Limits of Legal Imagination in International Affairs (1986).

39 For the argument that the criteria for the definition of the 'self' in self-determination are constructed rather than pre-ordained Berman, 'Sovereignty in Abeyance: Self-Determination and Intemational Law', 7 Wisconsin Joumal of Intemational Law (1988) 51.

40 See also Carl Zeiss Stiftung v. Rayner \& Keeler and Hesperides Hotels v. Aegean Turtish Holidays, supra note 10 and Gur v. Trust Bank of Africa, supra note 11 where the discussion apin centred on. and judicial discretion was exercised to protect, the rights of individuals. 
Choice and Evasion in Judicial Recognition of Governments: Lessons from Somalia

adjudicated upon might involve considering the interests of a government, a State, or a whole group such as the people of Somalia is not even addressed.

Even theorists sympathetic to international law have seen its reliance on the practice of States as rendering the task of distinguishing the legal from the political problematic; ${ }^{41}$ it is not surprising, therefore, that the portrayal of the international system as 'primitive' or pre-legal ${ }^{42}$ has not been eliminated and that textbooks on the subject still begin by trying to rebut this impression. Of course, as argued above, the distinction between law, fact and value is not as straightforward in domestic legal theory either. The difference between the international and domestic law systems is not one of kind but of degree: the interpretation of State practice may involve different techniques from the interpretation of statutes or constitutions but it is again interpretation, informed and conditioned, just like in the domestic system, by pre-conceived ideas, and ideals, about the purpose of the exercise. And if, as argued above, it is difficult to curtail the judges' discretion (or ease their predicament) in a domestic system by pointing to identifiable sources, the task is just as difficult, but not substantively different, in the international system, where the legal and the political have not been disentangled, even in theory.

In the final analysis, the inherently circular conception of custom cannot solve the problem of legitimacy: something 'extra' is needed to separate fact from value and to convert the 'is' of State practice into the 'ought' of obligation. This 'extra' cannot be other than a meta-theory, a political choice about how we should live and what we should believe. The question is whether such a meta-theory, or such a community of values and interests, can be found within the international system; to resolve cases such as Somalia we also need to look for a community not just within each domestic system but between them and the international system. Such a metatheory is indistinguishable from assumptions about the purpose of law in general and of international law in particular. It is in the light of such assumptions that interpretations of specific rules, including the test of effectiveness, will be made.

\section{Interpretation(s) of Effectiveness}

When one returns to the test for recognition of new governments we see again the same attempt to hide value judgments behind so-called 'factual' tests like effectiveness. We can see that it is no coincidence that in the area of recognition of governments the test of effectiveness was chosen over altemative contenders such as justice, constitutionality, willingness to honour international obligations or self-

41 See supra notes 32-34 and accompanying text

42 For the latter view see, e.g., Kelsen: 'General intemational law is primitive law and, like every primitive law, highly decentralized' in 'Recognition in International Law', 35 AIL (1941) 605, at 607 and Hart. 'it is submitted that there is no basic rule providing general criteria of validity for the rules of intermational law, and that the rules which are in fact operative constitute not a system but a set of rules' in The Cancept of Law (1961) at 230-31. 
determination. 'Effectiveness' shares the same attributes and assumptions as our system's predominant legal theory that is, it is meant to be based on observable, factual criteria rather than value judgments. Again, the assumption is that it is possible to divorce fact from value and policy not just in theory, but also in practice.

However, the history of attempts to deal with the acts of unrecognized regimes around the world confirm that both the test of effectiveness and its application are matters of contention. The following are some of the issues that make it unlikely that there will be a single answer to the dispute (the list is not exhaustive): firstly, is effectiveness to be equated with the 'success' of the purported new regime, as some cases suggest? ${ }^{43}$ If so, how is success to be assessed? Is military success sufficient or is approval and acceptance by the people also necessary? Secondly, when is success to be judged? How long does the regime have to survive before it can be called successful? Twenty-one days was thought to be enough in The State $v$. Dosso ${ }^{44}$ but two years and eight months was insufficient for the Privy Council in Madzimbamuto v. Lardner-Burke. ${ }^{45}$ Thirdly, if, as dicta suggest, effectiveness means habitual obedience what does the latter consist of? How big should the support be or how vocal the opposition? The revolutionary government in Grenada had been in place for four years and the new regime obtained a large majority at the elections but the court refused to hold that habitual obedience had been proved. 46 Fourthly, if consent by the people is to be a requirement, how is this consent to be ascertained? Elections can constitute a guide here but even then the issue of when to hold them and whether they were free and fair can provoke disputes. If obedience is sufficient by itself the issue of how much obedience is sufficient is again open to different interpretations. Thus, when for one judge 'there was no doubt' that the 1979 revolution in Grenada commanded popular support, another judge was not prepared to draw the same conclusion; when for one judge the fact that the prerevolutionary government only won one seat at the general elections was evidence of the popularity of the revolution, for another this was evidence that the old government still commanded strong support. ${ }^{47}$ Fifthly, even if one agrees on which facts are relevant, views on what those facts are usually diverge; different people (and different judges) may arrive at different conclusions using the same criteria and even the same set of facts. As the facts do not come neatly demarcated from their historical context but form part and parcel of that context, one may expect different interpretations of the facts depending on the context in which the interpretation takes place. At the same time, ignoring the context may lead to an incorrect assessment of the facts for only with the hindsight of history can one claim to be

The test of 'the successful revolution' validating the acts of an unconstitutional regime was applied in The State v. Dosso [1958] P.L.D. 533 and followed in Uganda v. Commissioner of Prisons, ex parte Matovu [1966] E.A. 514; Madzimbamuso v. Lardner-Burke [1968] 3 All ER 561; Ndhlovw v. The Queen [1968] 4 S.A.L.R. 515.

44 Supra note 43.

45 [1968] 3 All ER 561.

46 Mitchell and Other v. Director of Public Prasecutions and Another [1986] L.R.C. 35.

47 Ibid, at 73-75. 
making a correct assessment ${ }^{48}$ To appreciate that one would have to look not only at the Foreign Office's and one international organization's assessment of the situation but also at Somalia's recent history. Here, Hobhouse J, whilst insisting that the facts are paramount and that the courts can have a different voice from that of the government on the issue, in reality spends little time enquiring into those facts and relies, in the end, purely on assessments by the Foreign Office and a pronouncement from the Agency for International Development.

Madzimbamuto $v$. Lardner-Burke is just one example of a case where judges who purport to agree on the applicable test reach different conclusions because of their differing appreciation of the facts: at first instance ${ }^{49}$ it was thought that although the revolution was successful internally it was less certain whether it had shaken off its ties with the mother State. In the Appellate Division of the High Court, ${ }^{50}$ two judges held the regime to be internally de jure and its acts legally binding while the third concluded that it could not be said that the new government was so firmly established as to justify a finding that its status is that of a de jure government. And in the Privy Council it was thought that although the regime was successful and effective internally, as the mother State was still trying to crush the rebellion, the new government could not be said to have attained de jure status internally. ${ }^{51}$ Only a few weeks later, however, the Appellate Division of the Rhodesian High Court held unanimously in a new case that the regime had become de jure as sanctions imposed by the United Nations would fail and the regime was likely to continue. 52

While the above factors make assertions of definitive and conclusive interpretations difficult to sustain, they are themselves subsets of a greater dilemma which makes the prospect of neutral interpretation even more remote: the concept of effectiveness requires a judgment to be made about the purposes by reference to which effectiveness is to be judged: one cannot call something effective without some a priori criteria as to what effectiveness is for. This act of interpretation, projecting (or imposing) meaning onto the concept, cannot be determined by the concept itself (that would make the interpretation tautologous) but by an external, political choice. One may be effective, as Hitler's and Pol Pot's regimes were, at massacring thousands of innocent civilians. But if, as Hart himself insisted, there is a difference between the gunman's orders and the law, ${ }^{53}$ then we must accept that there are different ways of being effective and to assert one criterion of effectiveness over another is to return, unavoidably, to making a value judgment. In that sense, 'governmenthood', like statehood, is a relative concept; it does not follow 'as a matter of fact' but as a result of a political choice. The test also ignores

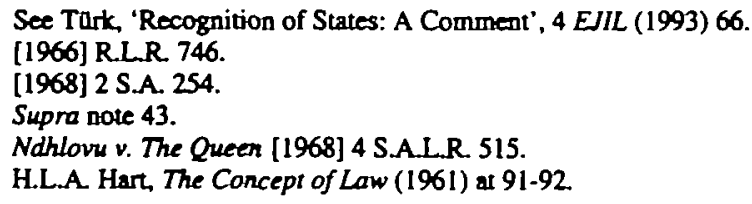


the extent to which the criterion of effectiveness is circular. to recognize something as effective accords a degree of status to it which it did not previously have and is likely to enhance its effectiveness. Like the concept of statehood and, one can say, all legal concepts, it is circular. clothing it with legal significance gives it a power it did not previously have. If this feature does not make the concept indeterminate it is difficult to see what does.

It is not surprising, therefore, that courts and commentators have disagreed not just on the application of the test of effectiveness but also on the relevance of the test itself; some bave rejected the test altogether, protesting that by making effectiveness the sole criterion of legality the issues of morality and justice of the new legal order are left out of consideration. ${ }^{54}$ As one judge put it,

a theory about law which seeks to exclude considerations of morality and justice cannot be made the binding rule of decision in the Courts of this country. 55

For some, the reason why the old order was overthrown (was it corrupt, inept or exploitative or was it popular and democratic), the motives of the rebels (were they fighting a just cause, did they command popular support or was the motivation mere power grabbing), the motives behind the people's obedience (was it due to fear or approval of the new regime) are all relevant factors. In Mitchell $v . D P P^{56}$ the Grenadan Court of Appeal concluded that for a revolutionary government to be considered legal, the revolution should not only be successful and the new government firmly established, but there should be general obedience based on consent and approval rather than fear and the new regime should not be oppressive or undemocratic.

Hobhouse J's assumption that effectiveness is a legal criterion when all other considerations are political, conceals the fact that both the choice of the test of effectiveness over other criteria and the application of that test to the facts of the case are not self-determining but for the judge to decide. Positivism in general purports to identify the 'rules' without reference to law's purpose, but the rules themselves contain an ideological choice: that effectiveness is more important than justice, or self-determination, or democracy. The crucial question therefore is not whether a certain government is effective but why effectiveness is important; choosing the test of effectiveness does not explain why the system is binding or legitimate, it only describes the fact that it has the physical power to bind and may be hiding law's preference for the stronger party. In this way, the conceptual structures chosen by the law are not neutral but create patterns of preference for one substantive outcome rather than another. 
We are faced, once again, with the fact that formalism cannot reach decisions by itself: for that, one needs to make a political choice. This means that despite some commentators' optimism, Hobhouse $\mathrm{J}$ has not succeeded in separating the legal from the political; no one (fortunately) can do that. What he has done is to create a legal fiction, that effectiveness is a legal criterion; in that way, he succeeds in 'reifying effectiveness', 57 in hiding, or suppressing, the fact that one both has, and should make, a political choice. The most likely effect of the abdication of this choice is to give, as in this case, an unquestioned reinforcement to the status quo. This concealment and evasion of the choice is unfortunate: as lawyers and as judges we should acknowledge, delight in, exercise, and be prepared to justify our exercise of this choice; we must remember that it is not legal rules and concepts that dictate outcomes and that the latter are not as rigid or self-determining as formalists would have us believe. Above all, we must remember that our decisions are based on our own pre-existing conceptions rather than on anything intrinsic to law; those preconceptions are none other than what we regard as politically right and just and to ignore them is to evade our responsibility as academics and as judges.

\section{Law's Purpose(s): New World (Dis)Order?}

Value judgments about law's purpose are, of course, assumed by all theorists: the political choice behind Hart and Kelsen's wish to separate law from morality and present law as a fact divorced from political and moral opinions was a commitment to pluralism and the rule of law. By presenting law as separate from the political system and containing its own internal logic, it was possible to present it as neutral and objective. In the same way, Fuller's quarrel with Hart was informed by Fuller's own desire to portray law as separate from the ends of immoral legislators by arguing that laws which did not conform to certain procedural requirements were not laws at all. 58 Dworkin's denial of the possibility of separating law from morals is also accompanied with a faith in the rule of law, the elimination of judicial discretion and the possibility of objective as well as flawless decision-making. However, Dworkin's assault on the distinction between legal and other standards comes to haunt his own distinction between principles and policies, leaving many with the impression that a laudatory aspiration for objectivity and perfection in judicial decision-making is elevated into a description of affairs which is nothing more than a grand illusion or a noble dream. ${ }^{59}$ When one seeks to use Dworkin's

57 The term is James Boyle's who defines it as an attempt to deny contingency and choice 'by incorporating some political decision about a subject into a description of that subject': Boyle. 'Ideals and Things: International Legal Scholarship and the Prison-house of Language', 26 Harv. Int'l LJ. (1985) 327, at 329.

58 Harh 'Positivism and the Separation of Law and Morals', 71 Harv. L Rev. (1958) 593; Fuller. 'Positivism and Fidelity to Law', 71 Harv. L Rev. (1958) 630.

59 Hart, 'American Jurisprudence Through English Eyes: The Nightmare and the Noble Dream', 11 Georgia Law Review (1977) 5. 
insights on the international sphere the problems multiply: even if one could distinguish between principles and policies, what are the principles, or rights and duties, governing the relations between equal and sovereign States? And what are the policies, or social goals, of the international community? If these principles are derived from that society's consensus on its moral values, is there such a thing as a common international morality?

For the makers of the UN Charter and post-World War jurists such as Hersch Lauterpacht the panacea for an effective international law system in this, and in all, instances, would be a supranational, centralized and hierarchical coercive legal system. ${ }^{60}$ Almost fifty years later, and with the Cold War behind us, President Bush ventured a similar ideal: as he pronounced during the Gulf Crisis, 'What is at stake is more than one small country: it is a big idea: a new world order - where diverse nations are drawn together in common cause, to achieve the universal aspirations of mankind: peace and security, freedom and the rule of law'.61 An attempt to lay down a common set of international law criteria for the recognition of new governments was made by European Community heads of State at their meeting in Brussels in December 1991; their criteria for recognizing new States in the former Soviet Union and Yugoslavia were such that they could not but address the type of new governments they preferred to see: such States, they demanded, must show a commitment to the rule of law and democracy, respect human rights and undertake to protect the rights of minorities. ${ }^{62}$ The classical criterion for recognition of States, that of the effectiveness of their governments, ${ }^{63}$ was not mentioned.

Unlike former Yugoslavia, where the EC's practical capabilities could not match either their theories or hopes, Somalia seemed ideal as the testing ground for the new world order, the conflict was localized, the United Nations was invited in by some of the warring factions, and for once it commanded the muscle of money of its member nations. ${ }^{64}$ But this attempt at 'assertive multilateralism' 65 floundered as national contingents refused to obey orders from foreign commanders, United Nations soldiers were accused of abusing their authority ${ }^{66}$ and those once welcomed to feed the hungry were denounced as neo-colonialist oppressors. For the United States itself the attempt to capture General Aidid proved a fiasco leading to tragic

60 Lauterpacht, 'The Law of Nations, the Law of Nature and the Rights of Man', 29 Grotius Society Transactions (1943). For support of this view sec Falk. 'A New Paradigm for International Legal Studies: Prospects and Proposals', 84 Yale Law Review (1975) 1.

61 Newrweek, 29 January 1991.

62 For support of the view that government as one of the elements of statehood must mean democratic government see Franck. 'The Emerging Right to Democratic Governance', 86 AJIL (1992) 46 and Fox. 'The Right to Political Participation in International Law', 17 Yale J. Int'l L (1992) 539.

63 Article 1, Montevideo Convention on the Rights and Duties of States, 1933.

64 Twenty-three countries provided 21,500 troops and a S1.5 billion military budget: Newsweek, 17 May 1993.

65 Madeleine Albright. US Representative to the United Nations, quoted by Newrweek, 26 July 1993.

66 Contained in a report published by African Rights, Somalia: Human Rights Abuses by the United Nations (July 1993); these allegations have been denied by the United Nations Secretariat. 
loss of life on all sides. Time and again United States and United Nations' goals were checked by lack of understanding of the cultural gulf between Western ideas and Somali aspirations; the UN's clumsy attempt to capture Aidid by putting up yellow WANTED posters and offering a $\$ 25,000$ reward to anyone who turned in Aidid to Gate 8 of the United Nations compound is just one example of this gulf. As a final affront to modernism's arrogant ambition to conquer the world through science, Washington's supersnoop capability was powerless in tracking Aidid's low-power radio transmitter: as one Pentagon aide put it, "low tech is baffling high tech'.67

Such reaction taught that appeals to ideals such as common purposes and principles, human needs, self-interest, or interdependence are too vague, abstract and controversial to found a universal law: principles such as justice, humanitarian ethics, world order and good faith are subject to differing interpretations and cannot claim to be neutral or self-applying. In the context of Somalia, the United Nations' attempt to halt the fighting for long enough to establish legitimate governing institutions was hampered by the fact that there was not even agreement on the meaning of legitimacy. The European Community's criteria for the recognition of States cannot help as they make their own assumptions about which political systems are better than others. Above all, the Somali experience taught that before one can have a supranational authority one must have a supranational agreement on principles governing the relations between States. But the world is too far from reaching a consensus as to what the purpose of international law should be: an international community is no less 'imagined', or constructed, than a national one.68 The assumption, therefore, of a community of principles between the domestic and international systems required to solve a scenario such as Somalia's, becomes even more tenuous.

Faced with such odds, attempts to present certain rules as universal only succeed in hiding, or suppressing, heterogeneity and difference behind a fiction of consensus. The fact that definitions and explanations of the binding quality of international law are neither neutral nor, however, ineffective can be gauged from the way in which their conceptual structures have dominated and delimited the portrayal of international law in recent decades without regard to alternative ways of delimiting it in Third World circles. The discourse of international law is a powerful element in its own right, creating conceptual structures which become entrenched and which are used to exclude and undermine alternative ways of looking at the world. ${ }^{69}$ As with our experience on the domestic plane, the liberal ideal that the

67 Newsweek, 18 October 1993.

68 See B. Anderson, Imagined Communities: Reflections on the Origin and Spread of Nationalism (1991).

69 This insight from Foucault's Power/Knowledge is investigated in the context of legal theory in P. Fitzpatrick, The Mythology of Modem Law (1992); for examples of its importance in the context of international law discourse see F.E. Snyder and S. Suthirathai, Third World Attitudes Toward Insemational Law: An Intraduction (1987) and K. Gunther and W. Benedec (eds), New Perspectives and Conceptions of International Law: An Afro-European Dialogue (1983). 
orthodox view of international law is meant to embody only succeeds in hiding as well as perpetuating inequalities between the participants. ${ }^{70}$ Despite the UN Charter's pronouncement of the principle of the sovereign equality of States, no one can deny that some States are more equal than others; by treating them as equal the international system only succeeds in reproducing those inequalities, both during the law-making as well as the law-enforcing stage. In these circumstances, any pronouncements such as President Bush's New World Order are easy prey to charges that what is referred to is US, or Western, order and that the so-called common principles informing the international system are Western criteria, not universal. ${ }^{71}$

Above all, such attempts assume that there is a privileged standpoint from which to view and order the world, a foundational truth with which to judge State actions. For those who do not share that standpoint or the faith in the same truth, such definitions and conceptual categories are constructed rather than given and cannot be used to justify the exercise of physical power. As Soawh J protested in Sallah $v$. The Attorney-General of Ghana 'one is entitled to ask whether theories propounded by the great jurists ranging from the time of Plato, Marx on to Hans Kelsen are immutable and of general application and whether those theories must necessarily fit into the legal scheme of every country and every age? I do not think so', he says, concluding that 'we will not derive much assistance from foreign theories'. ${ }^{72}$

\section{Choice and Responsibility in Judicial Decision-Making}

Both the domestic and international legal systems deal in life and death, arrogating to themselves the power to determine the circumstances in which force may be exerted; both, therefore, need to explain why their prescriptions should be followed. Attempts to express or, depending on one's viewpoint, create, a basis for international law are ongoing: Thomas Franck puts forward a version of procedural natural law in order to explain why rules bind, arguing that words are not as elastic and indeterminate as Wittgenstein might have us believe and that government as one element of statehood means democratic government. ${ }^{73}$ In a similar vein, Fernando Teson argues that sovereignty means domestic legitimacy and attempts to reaffirm the Kantian view of international law as based on the normative status of the individual. ${ }^{74}$ Support for this view can be found from human rights theorists

See, e.g., Sathirathai, 'An Understanding of the Relationship Between International Legal Discourse and Third World Countries', 25 Harv. In'l LJ. (1984) 395; sec also Weller, 'The Lockerbie Case: A Premature End to the New Wortd Order?', African Jownal of Intemational and Comparative Law (1992) 302

71 See, e.g. Chomsky, 'Wordd Order and its Rules: Variations on Some Themes', 20 Joumal of Law and Society (1993) 145.

Supra note 48.

The Power of Legitimacy Amang Nations (1990).

Teson, 'The Kantian Theory of Imternational Law', 92 Colum. L Rev. (1992) 53. 
Choice and Evasion in Judicial Recognition of Governments: Lessons from Somalia

who have similarly argued for the primacy of the individual over statist conceptions of international law. ${ }^{75}$ Others have looked for the purpose of the international system in a substantive theory of justice, trying to derive universal principles of international law from a hypothetical social contract. ${ }^{76}$

The difficulty with such attempts is that law, domestic and international, has not one but many and diverse purposes; it is not surprising that some conflict, especially when the issue straddles two different systems, neither of which is successful at convincing everybody of its own legitimacy. Both systems rely on the (inevitably subjective) interpretation of values in societies which cannot claim to share a consensus on those values. The only way out of this dilemma is to acknowledge the indeterminacy of legal rules and the absence of a final arbiter for the resolution of conflicts. Rather than looking for totalizing and all-encompassing solutions which impose, rather than reflect, a consensus or a community, one should be eclectic about legitimizing principles and restrict oneself to contextual solutions: rather than looking for universal principles and world law one should look for particular solutions to particular problems. ${ }^{77}$ Such an approach would accompany, in the international sphere, the end of our conviction in modernity's legitimizing metanarratives that we encountered on the domestic plane. It would mean the abandonment of the search for a single, unitary theory which ignores diversity in culture and aspirations and the acknowledgement of difference and the existence of and search for incompatible goods. Above all, rather than imposing another 'reified' concept, such as effectiveness, as if it were universal, it would mean admitting and dealing with diversity and difference.

Legal positivists and Dworkin were not, of course, alone in trying to suppress politics, value and opinion from their investigations and definitions of law; nor were they the only ones to try and iron out irregularities and differences under the rubric of one theory or one idea. Positivism is just one manifestation of the modern project to develop objective science, universal morality and law and autonomous art. ${ }^{78}$ And although sometimes portrayed as radical and nihilistic, legal realists also shared in the modernist project when they assumed that, even though law was indeterminate,

75 See, e.g. Reisman, 'Sovereignty and Human Rights in Contemporary International Law', 84 AJIL (1990) 866.

76 Skubik, 'Two Models for a Rawlsian Theory of International Law and Justice', 14 Denv.J.Int.L.\& Pol. (1986) 231.

77 For support of this view in general legal theory see R.M. Unger, Law in Modem Sociery, Toward a Criticism of Social Theory (1976); and in international legal theory see M. Koskenniemi, From Apology to Utopia: The Structure of Intemational Legal Argument (1992). The latter proposes a foundationless hermeneutic or 'perspectivism' where conflicting idesls of social organization are equally respected and where each arrangement remains revisable (at 500 ).

78 See Habermas, 'Modernity - An Incomplete Project', in H. Foster (ed.), Pastmodem Culture (1985): 'The project of modernity formulated in the 18th century by the philosophers of the Enlightenment consisted in their efforts to develop objective science, universal morality and law and autonomous art accoiding to their inner logic' (at 9). See also T. Adorno and M. Hortheimer. 'the program of the Enlightenment was the disenchaniment of the wortd: the dissolution of myth and the substitution of knowledge for fancy': Dialectic of Enlightenmens (1979) at 3. 
science was certain. ${ }^{79}$ These assumptions and these hopes inform the whole of our domestic legal system and approach to judicial decision-making. It is not surprising, therefore, that it is found in our judges' treatment of international law in general and the recognition of foreign governments in particular. Since international law theorists, historians and politicians are themselves undecided about the purposes, principles and policies informing the international system, it is not surprising that judges refrain from dealing with intemational law directly and resort instead to the safety of domestic law. By treating international law as 'fact', capable of ęvidential proof, they avoid having to deal with the value judgments embedded in that law and, more importantly, of choosing between different values in hard cases such as Somalia. The reluctance to choose is evident not only in their deference to pronouncements by Her Majesty's Government but also in their choice of the test of effectiveness. Even if Hobhouse J purports to go beyond what the Foreign Office says to lay down a separate 'legal' test, the latter does not differ greatly from the test adopted in previous decisions: irrespective of who decides, Her Majesty's Government or the Court, the underlying theme and criterion is the same, that is, effectiveness.

The approach adopted in this case conforms therefore to the modernist attempt to suppress opinion and politics and to present law, domestic or international, as value-free, objective and scientific. This approach is not entirely honest: the test of effectiveness cannot help but contain its own criteria of value and therefore its selection over other criteria means that judges always had a choice as to the outcome and always will. ${ }^{80}$ Positivism, by operating as if facts and tests can decide the issue, closes those options and hides the value judgments embedded in them. It forgets that neither the facts nor the rules are self-selecting or self-defining and finishes by tying its hands with its own, self-imposed, tests. Moreover, it does so without enquiring into the suitability of those tests to the particular case in issue; the most frequent outcome of this unquestioning approach is to reaffirm the status quo. This is nowhere better exemplified than in the result of this judgment; the court declines to make a value judgment and abdicates responsibility on the issue by leaving things as they are.

Ultimately, the crucial issue is not whether our decisions are based on facts as opposed to values, principles, or policies but on which facts, and which values; no 'fact' can be normative without an anterior criterion as to what is relevant and what is irrelevant and neither the facts nor the rules can determine an outcome by themselves. It is no good, therefore, to pretend that facts are going to determine the issue: we will have to find the answer, make the choice, and, ideally, be able to defend it. No doubt law is political, no doubt it is difficult to separate legal from political criteria, whether in domestic or intemational law. The real issue is what is the policy and is it a good one? Effectiveness by itself, however, is uninformed,

79 See Duxbury, 'The Reinvention of American Legal Realism', 12 Legal Srudies (1992) 137.

80 See Lord Wilberforce in Carl Zeiss Stiftung v. Rayner \& Keeler, and Lord Denning in Hesperides Hotels v. Aegean Turtish Holidays, supra note 10 and accompanying text. 
unquestioning and ultimately meaningless, policy. To ask for greater attention to contex, on the other hand, means enquiring into whether the government, recognized or not, would be effective in attending to that society's most pressing problem, that is, of feeding its starving population.

In the final analysis, one cannot escape the task of choosing; to do so would be to behave like Ts'ui Pen in The Garden of Forking Paths, ${ }^{81}$ who, when writing his novel, follows every option open to him; the result is to write a story that is incomprehensible to anyone but himself. The writing of, and living within, the law presents the same dilemma: the human craving for order, stability and predictability means that we will submit to rules, often of our own making, and often unquestioningly, rather than face anew the task of choosing. What is important, however, is to preserve our capacity to choose and to be prepared to explain and defend that choice. To do otherwise would be to fail in our responsibility as academics and as judges. We must remember, above all, that things only become legal when we recognize them as legal, for legality, like other ideals, is a circular notion, an illusion which exists only when we ourselves acquiesce in it. The reification of 'effectiveness' into a legal test is another addition to this fiction and only exists for those ready to embrace it. This view is not exclusive to critical lawyers: Kelsen himself admitted that facts cannot decide the issue and that it is the investment of those facts with legal authority that is the crucial stage in the legal process. That investment can only follow from a political decision: "in the realm of law there is no fact in itself, no immediately evident fact; there are only facts ascertained by the competent authorities in a procedure determined by law. ${ }^{82} \mathrm{Or}$, as Joseph K. put it, 'it is only a trial if I recognize it as such'. ${ }^{83}$

81 J.L Borges, Labyrinths (Penguin; 1970): 'in all fictional works, each time a man is confronted with several alternatives, he chooses one and eliminates the others; in the fiction of Ts'ui Pen, he chooses - simuttaneously - all of them' (at 51).

82 Supra note 5, at 388.

83 F. Kafke, The Trial (Penguin; 1986) at 49. 